\title{
Millennials' Service Quality Expectations: A Challenge for Academic Librarians
}

\author{
Sajeewanie D. Somaratna ${ }^{1}$
}

\begin{abstract}
Millennials, the users of today's academic libraries are socially and culturally more diverse than previous generations. They are Internet savvy, always connected to social media and leaning to multitasking. The purpose of this study was to explore the millennials' expectations of service quality of academic libraries and specific objectives were set; to assess millennials' expectations of service quality, to identify the most important service quality attributes and to identify millennials' anticipation of spending of limited library allocation. A user survey was conducted among the first year Science students of University of Colombo and 250 questionnaires were distributed among the students. The survey questionnaire was designed taking inputs from SERVQUAL and LibQUAL models and included questions on user expectations of the service quality (physical facilities, library resource, library services, and staff), most important service quality attributes and user anticipation of spending of library allocation. In addition, open questions on the additional expectations of library service quality. Students rated their expectations in a fivepoint Likert scale ranging from strongly disagree (lowest) to strongly agree (highest). Most of the service quality attributes were selected by millennials with more than $80 \%$ expectation level and "Internet connectivity and Wi-Fi facilities in the library" (2.237) was ranked as the most important service quality attribute for each student followed by "comprehensive printed resources" (2.167), "convenient library opening hours"(2.08), "self-study areas" (1.878) and "group study areas" (1.872). According to the millennials' anticipation of limited library allocation, $87 \%$ of the students selected the library collection development is more important than the improvement of physical facilities (13\%). They selected the development of the printed collection $(52 \%)$ over the electronic collection $(48 \%)$ and library learning space expansion $(84 \%)$ over the improvement of library equipment (16\%). Library administration needs to discuss these specific needs of "always connected" generation and address them very carefully to build up a strong relationship between the millennials and the academic library.
\end{abstract}

Keywords: Academic libraries, Millennials, Service quality, User expectations

\footnotetext{
${ }^{1}$ Senior Assistant Librarian, Faculty of Science, University of Colombo, Sri Lanka, E-mail: sajees@lib.cmb.ac.lk, (D) https://orcid.org/0000-0003-1128-1330
} 


\section{Introduction}

The library is the centre of the academic world by providing access to world-class information for teaching, learning and research. According to Ranganathan's five laws of library science, the most important philosophy of any library is to serve its users with quality information resources and services. Although the basic philosophy remains the same, the tools and techniques of providing such resources are changing due to technological innovations. "Ranganathan's laws go beyond print resources to include electronic resources while access to information resources is going beyond physical access to remote access by crossing geographical barriers" (Keralapura, 2009, p. 184).

Today libraries are used by millennials who born after 1982, that includes the majority of students currently enrolled in universities, recent graduates, and future university students. They are also labeled generation Y, the net generation, the digital generation, or the eco-boom generation (Becker, 2009 and Sweeny, 2005). They are deemed different from past generations, with different habits, expectations, and skills, which mythically transform them into the Web experts and virtual entrepreneurs of our digital future. (Becker, 2009). They often do their academic work as groups, either with or around their friends or batch-mates, making ample use of technology and digital content. They also work on late in the day and into early morning (YooLee et al., 2013). Further according to Yoo-Lee et al. (2013) the common attributes of this generation that can be particularly relevant to libraries are: socio-culturally more diverse than previous generations; internet savvy; always "connected" to social media; and tendency to multitasking. Libraries need to understand the expectations of millennials' and provide spaces to reinforce the social aspects of learning by combining technology, service, and atmosphere to create a dynamic, comfortable, and collaborative environment (Yoo-Lee et al., 2013).

From the early 1990s with emerging of millennial students, the increasing use of the Internet and off-campus availability (remote access facilities) of electronic resources have resulted in a decline of traditional uses of academic libraries (Yoo-Lee et al, 2013). This was evident mainly in areas of circulation of print materials and reference services. Also, Academic libraries have been challenged to use their physical space in different ways and the library community has responded to this challenge by creating and implementing new facilities and services. These are called "social spaces," like cafes, collaborative group study spaces and "learning commons." Major driving forces toward this movement include: a shift in pedagogy in higher education that has placed more stress on group projects and collaborative work and a focus on millennial students' learning and working styles. (Yoo-Lee et al, 2013).

Since millennials began to enter Universities, librarians have been discussing the best strategies for reaching and attracting the digital generation. Weiler (2005) found that the millennial generation has a different approach to research and the amount of time they are willing to wait to receive help and information (Weiler, 2005). Sweeny (2005) discussed modifying library buildings and spaces in order to tap into the preferences of social space and room for collaboration of millennials. Similarly, 
Gardner and Eng (2005) searched the preferences of millennials when it comes to service and suggested ways of adapting library services to meet their needs.

The OCLC study (2010) by De Rosa et al., (2011) on the "perceptions of the libraries, 2010 " shows "a majority of people using search engines in preference to library resources has been a cause of some alarm among librarians who see libraries in danger of losing their place as the primary information provider to academics and the general public" (Fialkoff, 2006 cited in Jia Mi and Nesta, 2006, p.411). Therefore libraries do need to look, how they should communicate with their users, here millennials, that their users is being attracted to other services (Fialkoff, 2006).

However, the academic libraries in Sri Lanka are not fully adapted to cater the millennial students' expectations (Mashroofa, 2013). This scenario has created a huge gap between the millennial students and academic libraries and it is evident by the rapid decline of library usage by current students. They have repelled from traditional library materials such as books, periodicals and on the other hand, they extensively use E-resource centres with Internet facilities. The main crisis behind this is the tendency of students' total dependency on Internet (www) to find "on the spot" solutions for their information queries without even evaluating the quality and reliability of information sources. They also refuse traditional library services and expect a new set of modern library services such as collaborative learning facilities with more social interactions in a comfortable library environment. Every year library administrators take efforts to develop library facilities to fulfill user requirements but most of the academic libraries in Sri Lanka are still practicing traditional policies and norms especially in the areas of collection development and learning space designing.

Therefore, to explore the millennials' expectations from an academic library in this digital era following objectives were set: to assess millennials' expectations of service quality of academic libraries, to identify the most important service quality attributes for millennials and to explore the millennials' anticipation of spending of limited library allocation.

\section{Methodology}

By adopting a survey method, a user survey was conducted among the first-year students (new intake) of the Faculty of Science, University of Colombo at the orientation programme in February 2018, before they experience a university library. A type of purposive sampling technique, the total population sampling was carried out and 250 questionnaires were distributed among the students who participated for the orientation programme and the response rate was $100 \%$. All the students were born in either 1995 to 1997 and their ages were 20 years to 22 . Nearly 52\%of the student sample was male students while $48 \%$ was female students.

The survey questionnaire was designed taking inputs from SERVQUAL (Parasuramanet al, 1988) and LibQUAL (Moon, 2006) models and included questions on user expectations of the service quality (physical facilities, library resource, library services and staff), most important service quality attributes and user 
anticipation of spending of library allocation. In addition, open questions on the additional expectations of library service quality. Students were asked to rate their expectations in a five-point Likert scale ranging from strongly disagree (lowest) to strongly agree (highest). To identify the most important attributes from the listed attributes they were asked to select the first three most important attributes for each of them. Users' preference on spending of limited annual library allocation was explored by adding multiple choice questions.

Data analysis was done using both qualitative and quantitative techniques. User expectations and their preferences on spending limited library allocation were calculated using percentages and the most important attributes identified by millennials, were analyzed by Average Ranking formula (SurveyMonkey, 2019).

$$
\text { Average Ranking }=\frac{x_{1} w_{1}+x_{2} w_{2}+\ldots \ldots+x_{n} w_{n}}{\text { Total response count }}
$$

$w=$ weight of ranked position

$x=$ response count for answer choice

\section{Results and Discussion}

\section{Service Quality Expectations of Millennials}

Convenient library working hours, self-study areas in the library, comfortable furniture and physical facilities, comfortable and inviting environment (AC and lighting), comprehensive print resources (books, journals etc.), Internet connectivity and Wi-Fi facilities, error free records in the library, staff's ability to promise services to users by a certain time, staff's sincere interest/willingness to help users, staff who understand the specific needs of users were the most expected $(100 \%)$ service quality attributes of millennials. They ranked 'electronic security system in the library' (41\%) as the least expected service quality attribute and followed by 'coffee shop in the library building' (45\%) and 'networking with other libraries for interlibrary lending' $(68 \%)$. (Annex 1)

\section{Most Important Service Quality Attributes for Millennials}

The most important service quality attribute with the highest Average score was 'Internet connectivity and Wi-Fi facilities in the library' (2.237) and followed by 'comprehensive printed resources' (2.167) , 'Convenient library opening hours'(2.08), 'self-study areas in the library' (1.878), 'group study areas in the library' (1.872) and 'subscription to e-journals and e-books' (1.838). (Table 1 and Figure 1). Refraining from limiting their expectations to the technology, collection and the library space, millennials looked for the comfortability of the library environment by ranking 'Comfortable and inviting environment' and 'Comfortable furniture and physical facilities' among the first ten preferences. 
Table 1. Most important attributes ranked by Millennials with ranking scores

\begin{tabular}{|c|c|c|c|c|c|c|}
\hline & Attributes & $\begin{array}{c}\text { Priority } \\
1\end{array}$ & $\begin{array}{l}\text { Priority } \\
\quad 2\end{array}$ & $\begin{array}{c}\text { Priority } \\
3\end{array}$ & Total & $\begin{array}{c}\text { Ranked } \\
\text { Average } \\
\text { Score }\end{array}$ \\
\hline 01 & $\begin{array}{l}\text { Internet connectivity and } \\
\text { Wi-Fi facilities }\end{array}$ & $\begin{array}{c}64 \\
41.02 \%\end{array}$ & $\begin{array}{c}65 \\
41.66 \%\end{array}$ & $\begin{array}{c}27 \\
17.32 \%\end{array}$ & 156 & 2.237 \\
\hline 02 & $\begin{array}{l}\text { Comprehensive Print } \\
\text { Resources }\end{array}$ & $\begin{array}{c}52 \\
41.26 \% \\
\end{array}$ & $\begin{array}{c}43 \\
34.13 \% \\
\end{array}$ & $\begin{array}{c}31 \\
24.61 \% \\
\end{array}$ & 126 & 2.167 \\
\hline 03 & $\begin{array}{l}\text { Convenient library } \\
\text { working hours }\end{array}$ & $\begin{array}{c}13 \\
26.0 \%\end{array}$ & $\begin{array}{c}28 \\
56.0 \%\end{array}$ & $\begin{array}{c}9 \\
18 \%\end{array}$ & 50 & 2.08 \\
\hline 04 & $\begin{array}{l}\text { Self-study areas in the } \\
\text { library }\end{array}$ & $\begin{array}{c}16 \\
39.02 \% \\
\end{array}$ & $\begin{array}{c}4 \\
9.76 \% \\
\end{array}$ & $\begin{array}{c}21 \\
51.22 \% \\
\end{array}$ & 41 & 1.878 \\
\hline 05 & $\begin{array}{l}\text { Group study areas in the } \\
\text { library }\end{array}$ & $\begin{array}{c}28 \\
35.89 \% \\
\end{array}$ & $\begin{array}{c}12 \\
15.38 \% \\
\end{array}$ & $\begin{array}{c}38 \\
48.73 \% \\
\end{array}$ & 78 & 1.872 \\
\hline 06 & $\begin{array}{l}\text { Subscription to e- } \\
\text { journals/full-text databases }\end{array}$ & $\begin{array}{c}22 \\
29.73 \%\end{array}$ & $\begin{array}{c}18 \\
24.32 \%\end{array}$ & $\begin{array}{c}34 \\
45.95 \% \\
\end{array}$ & 74 & 1.838 \\
\hline 07 & $\begin{array}{l}\text { Comfortable and inviting } \\
\text { environment }\end{array}$ & $\begin{array}{c}12 \\
20.69 \%\end{array}$ & $\begin{array}{c}21 \\
36.21 \%\end{array}$ & $\begin{array}{c}25 \\
52.95 \%\end{array}$ & 58 & 1.776 \\
\hline 08 & $\begin{array}{l}\text { Comfortable furniture and } \\
\text { physical facilities }\end{array}$ & $\begin{array}{c}4 \\
11.76 \% \\
\end{array}$ & $\begin{array}{c}12 \\
35.29 \% \\
\end{array}$ & $\begin{array}{c}18 \\
52.95 \%\end{array}$ & 34 & 1.705 \\
\hline 09 & $\begin{array}{l}\text { Well maintained computer } \\
\text { \& equipment in library }\end{array}$ & $\begin{array}{c}8 \\
20.0 \%\end{array}$ & $\begin{array}{c}1127.5 \\
\%\end{array}$ & $\begin{array}{c}21 \\
52.5 \%\end{array}$ & 40 & 1.675 \\
\hline 10 & $\begin{array}{l}\text { Library resources } \\
\text { accessible through Website }\end{array}$ & $\begin{array}{c}4 \\
13.79 \%\end{array}$ & $\begin{array}{c}8 \\
27.59 \%\end{array}$ & $\begin{array}{c}17 \\
58.62 \%\end{array}$ & 29 & 1.551 \\
\hline
\end{tabular}

Internet connectivity and $\mathrm{Wi}$-Fi facilities

Comprehensive Print Resources

Convenient library working hours

Self-study areas in the library

Group study areas in the library

Subscription to e-journals/full-text databases

Comfortable and inviting environment

Comfortable furniture and physical facilities

Well maintained computer \& equipment in

Library resources accessible through Website

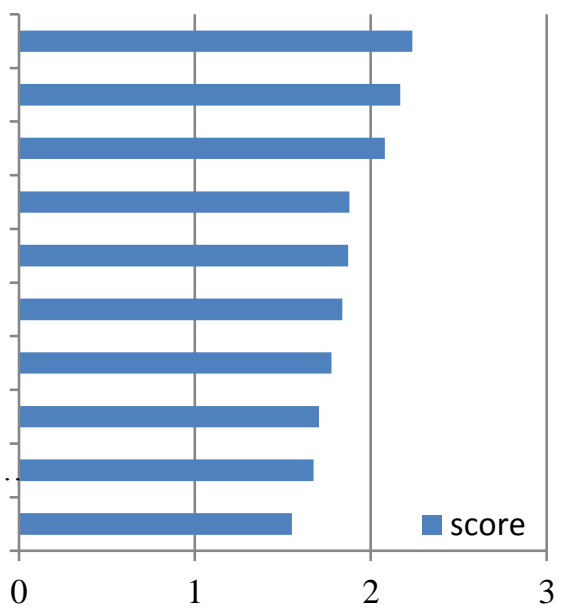

Figure 1. Most important service quality attributes ranked by Millennials 


\section{Spending of Limited Library Allocation to Improve Library Facilities}

Each year academic libraries are funded by Universities basically to improve two main fields; the collection and the physical facilities. According to the results, millennials are more concern about the collection development than Physical facility improvement. More or less equally they have selected both development of printed and electronic collection while learning space expansion was prioritized by them than the library equipment development. (Figure 2).

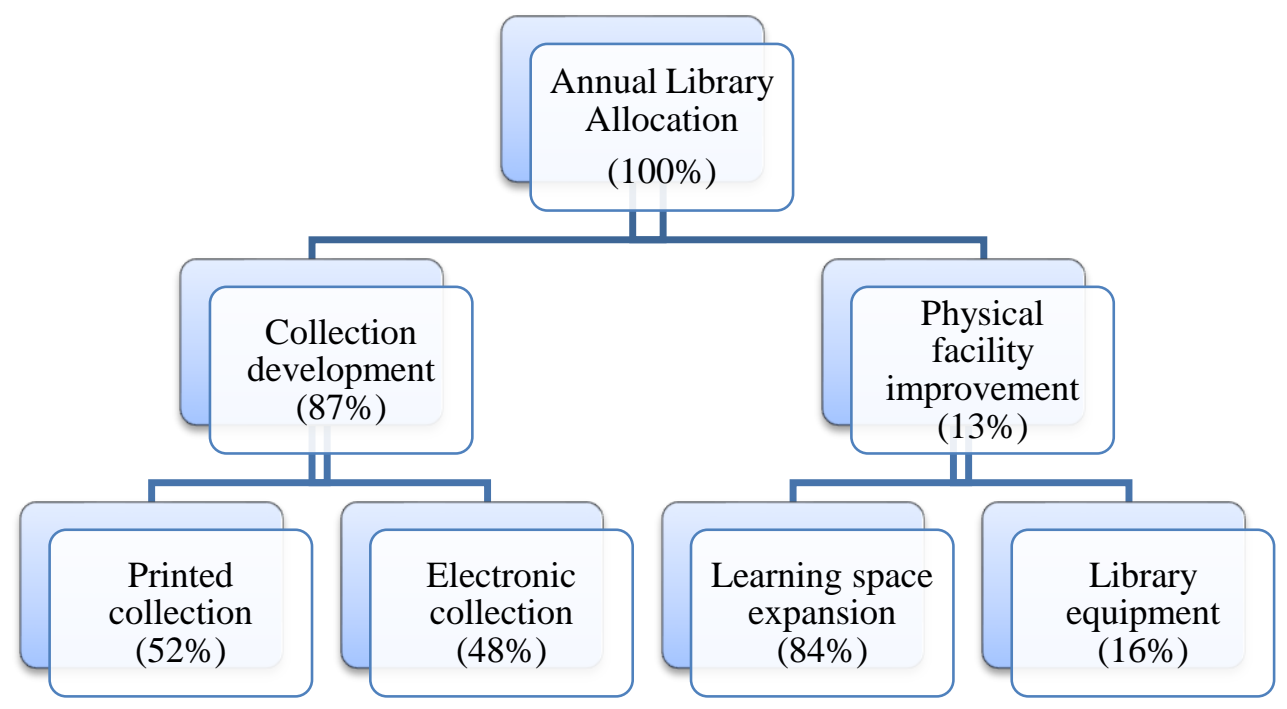

Figure 2. Millennials' anticipation of spending of limited library allocation

\section{Collection Development or Physical Facilities Improvement}

$87 \%$ of the millennials have selected library collection development is the most important over the improvement of physical facilities (13\%). (Figure 2). Complete collection for studies, include rare books in the collection, can comprise enough number of copies of textbooks, get enough information for assignments and can improve knowledge in several fields (not only Science) were given as reasons for selecting the collection development. Reasons for physical facility improvement were given as: enough space for self-studies, Internet and Wi-Fi facilities, meet with friends and do discussions, space to share knowledge and motivate them by the surrounding environment. (Table 2)

\section{Develop the Print Collection or Electronic Collection}

$52 \%$ of the students selected the development of print collection (books and journals) is the most important while $48 \%$ of the students selected the development of the electronic collection is the most important for them. (Figure 2). Reasons for selecting the printed collection development were easy to read for long hours, easy to do studies with printed materials, work without electronic devices and love to read books. 
Reasons for selecting the electronic collection development over the printed collection were easy to access, share and store, can read interactive books, can read from anywhere and for those with physical disability, the portability of a digital text can make studying more accessible. (Table 2)

\section{Improve the Library Equipment or Learning Spaces}

$84 \%$ of the students selected library learning space expansion over library equipment (16\%) such as computers, scanners, printers, etc. (figure 2). Reasons for learning space expansion were, to do self-studies, to meet friends, to do group studies, to escape from routing work/ relaxing and to read novels and magazines. Students identified, search study material, to do assignments, to interact with friends via emails/ social networks, to watch videos/ movies, to practice presentations and to obtain printing and scanning facilities as reasons for library equipment development. (Table 2)

Table 2. Millennials' preferences when spending the Annual Library Allocation

\begin{tabular}{|c|c|c|c|}
\hline \multicolumn{4}{|c|}{ Annual Library Allocation (100\%) } \\
\hline \multicolumn{2}{|c|}{ Collection development (87\%) } & \multicolumn{2}{|c|}{$\begin{array}{l}\text { Physical facilities improvement } \\
\text { (13\%) }\end{array}$} \\
\hline \multicolumn{2}{|c|}{$\begin{array}{l}\text { Reasons for the selection } \\
\text { - Complete collection for studies } \\
\text { - Include rare books in the collection } \\
\text { - Enough number of copies of } \\
\text { textbooks, } \\
\text { - Enough information for assignments } \\
\text { - Improve knowledge in several fields }\end{array}$} & \multicolumn{2}{|c|}{$\begin{array}{l}\text { Reasons for the selection } \\
\text { - Enough space for self-studies } \\
\text { - Internet and Wi-Fi facilities } \\
\text { - Meet with friends and do discussions } \\
\text { - Space to share knowledge } \\
\text { - Motivate them by the surrounding } \\
\text { environment. }\end{array}$} \\
\hline $\begin{array}{c}\text { Printed } \\
\text { collection }(52 \%)\end{array}$ & $\begin{array}{c}\text { Electronic } \\
\text { collection }(48 \%)\end{array}$ & $\begin{array}{r}\text { Lea } \\
\text { sp } \\
(8 \\
\end{array}$ & $\begin{array}{c}\text { Library } \\
\text { equipment }(16 \%)\end{array}$ \\
\hline $\begin{array}{l}\text { - easy to read for } \\
\text { long hours } \\
\text { - easy to do } \\
\text { studies with } \\
\text { printed } \\
\text { materials } \\
\text { - work without } \\
\text { electronic } \\
\text { devices } \\
\text { - love to read } \\
\text { books }\end{array}$ & $\begin{array}{l}\text { - read interactive } \\
\text { books } \\
\text { - read from } \\
\text { anywhere }\end{array}$ & $\begin{array}{l}\text { - do group } \\
\text { studies } \\
\text { - escape from } \\
\text { routing work/ } \\
\text { relaxing }\end{array}$ & $\begin{array}{l}\text { - interact with } \\
\text { friends via emails/ } \\
\text { social networks } \\
\text { - watch videos/ } \\
\text { movies }\end{array}$ \\
\hline
\end{tabular}




\begin{tabular}{|l|l|l|l|}
\hline & $\begin{array}{l}\text { portability of a } \\
\text { digital text can } \\
\text { make studying } \\
\text { more accessible }\end{array}$ & $\begin{array}{l}\text { read novels and } \\
\text { magazines }\end{array}$ & $\begin{array}{l}\text { practice } \\
\text { presentations }\end{array}$ \\
& & $\begin{array}{c}\text { printing and } \\
\text { scanning facilities }\end{array}$ \\
\hline
\end{tabular}

\section{Other Expectations of Service Quality}

Other than the service quality attributes that listed in the questionnaire students identified, laptop and device charging facilities (19.2\%), student accounts to access library website from outside the university (12.8\%), a mobile app for library services $(12.4 \%)$, theater in the library to watch movies, video conferencing room in the library and easily accessible washroom facilities in the library as the additional expectations from a library (table 3 and figure 3 ).

Table 3. Other expectations of Millennials

\begin{tabular}{|c|l|c|c|}
\hline & \multicolumn{1}{|c|}{ Other expectations } & $\begin{array}{c}\text { Number of } \\
\text { requests }\end{array}$ & Percentage \\
\hline 01 & Laptop and device charging facilities & 48 & $19.2 \%$ \\
\hline 02 & $\begin{array}{l}\text { Student accounts to access library website from } \\
\text { outside the university }\end{array}$ & 32 & $12.8 \%$ \\
\hline 03 & Mobile app for library services & 31 & $12.4 \%$ \\
\hline 04 & Theater in the library to watch movies & 26 & $10.4 \%$ \\
\hline 05 & Video conferencing room & 24 & $9.6 \%$ \\
\hline 06 & Easily accessible washroom facilities & 12 & $4.8 \%$ \\
\hline
\end{tabular}

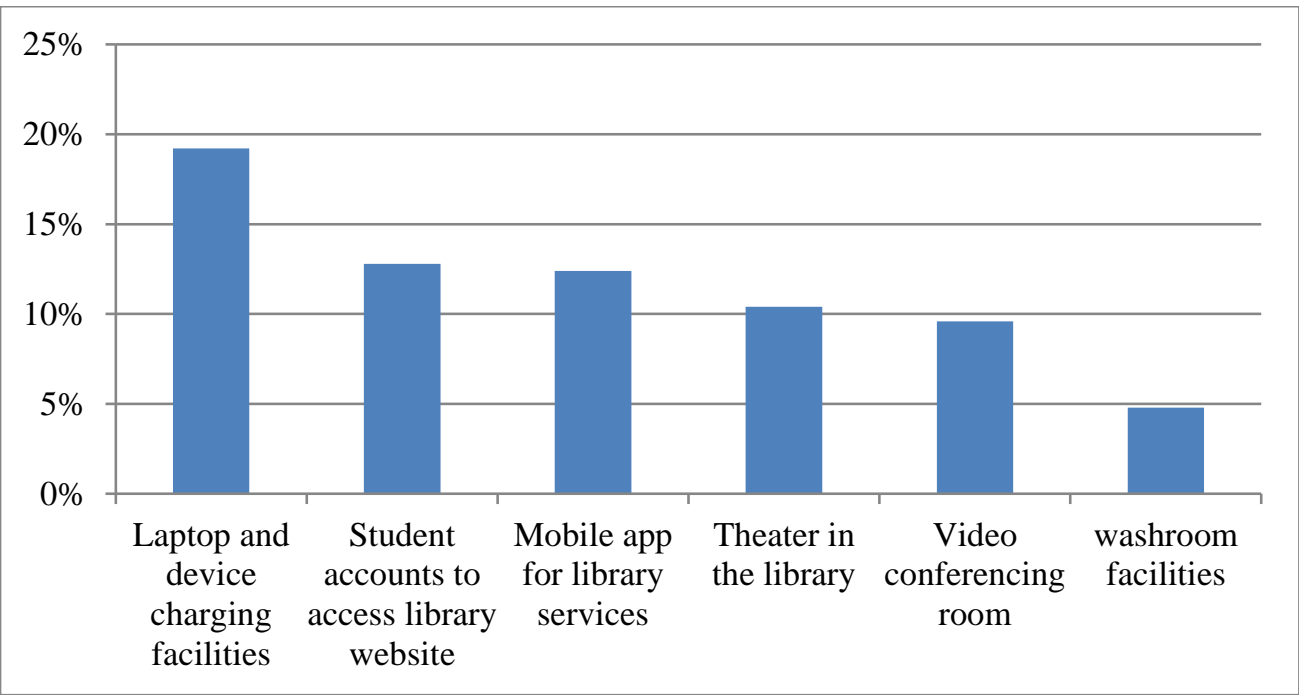

Figure 3. Other expectations of Millennials 


\section{Conclusions}

The highest ranked service quality attribute was the 'Internet connectivity and Wi-Fi facilities in the library' and followed by 'comprehensive printed resources', 'convenient library opening hours', 'self-study areas in the library', 'group study areas in the library' and 'subscription to e-journals and e-books'. While selecting the majority of the service quality attributes as millennials' expectations, lesser priority was given to three attributes: 'electronic security system', 'coffee shop in the library' and the 'networking with other libraries for Inter Library lending'. Library collection development was selected as the most important factor over the improvement of physical facilities when consider the spending of the annual library allocation. Students' expectation on development of the printed collection was slightly over the electronic collection and library learning space expansion was over the improvement of library equipment. Laptop and device charging facilities, student accounts to access library website from outside the university and mobile app for library services were among the other expectations of the millennial students.

\section{Recommendations and Further Studies}

While maintaining good printed collection in the academic libraries by preserving traditional values, it should adapt to make published information searchable through search engines and other millennial tools, provide many different types of library spaces carefully studied and marketed to millennials and need to redesign library spaces that can continuously, quickly, easily and cheaply adapt to new millennial expectations. Therefore Library administration needs to discuss these specific needs of "always connected" millennial students and address them very carefully to attract them to academic libraries.

Although this research has shed light on changing concept in academic libraries with millennials' expectations, there are interesting questions that remain and can be studied further: Strategies to satisfy millennials' expectations, discover the important personal competencies of academic librarians in the changing environment and reach beyond the annual book and periodical allocation of academic libraries.

\section{References}

Becker, Jr., Charles, H. (2009). Student Values and Research: Are Millennials Really Changing the Future of Reference and Research?, Journal of Library Administration, 49(4),341-364.

De Rosa, Cathy, Joanne Cantrell, Matthew Carlson, Peggy Gallagher, Janet Hawk, and Charlotte Sturtz. (2011). Perceptions of Libraries, 2010: Context and Community. Dublin, Ohio: OCLC. Retrieved from: https://www.oclc.org/content/dam/oclc/reports/2010perceptions/2010perception s_all_singlepage.pdf 
Fialkoff, F. (2006). "What's so bad about books?", Library Journal, 131, Retrieved from: https://www.libraryjournal.com/article/CA6298439.html.

Gardner, S. \& Eng, S. (2005). What Students Want: Generation Y and the Changing Function of the Academic Library. Portal: Libraries and the Academy 5(3), 405420. Johns Hopkins University Press. Retrieved from: https://www.shirleymohr.com/JHU/Sample_Articles_JHUP/PLA_2005_5_3.pd $\mathrm{f}$

Jia, Mi, and Nesta, F. (2006). "Marketing library services to the Net Generation", Library Management, 27(6/7), pp. 411-422

Keralapura, M. (2009). Technology and customer expectationin academic libraries: A special reference to technical/management libraries in Karnataka.International Information \& Library Review, 41(3), 184-195.

Mashroofa, M. M. (2013). Requirements of Net Generation towards university libraries in Sri Lanka. Journal of the University Librarians Association of Sri Lanka, 16(2), pp.101-116. http://doi.org/10.4038/jula.v16i2.5202

Moon, A. E. (2006). LibQUAL+TM at Rhodes University library: an overview of the first SouthAfrican implementation. In: FOTIM, Conference on Quality Assurance in Higher Education: Mission (Im)possible? Pretoria. Retrieved from: https://www.libqual.org/documents/admin/Moon_SouthAfrica.pdf

Parasuraman, A. et al. (1988). SERVQUAL: A multiple item scale for measuring consumer perceptions of service quality. Journal of Retailing, 64(1), 12-37.

SurveyMonkey (2019). Average Ranking. Retrieved from: https://help.surveymonkey.com/articles/en_US/kb/How-do-I-create-a-Rankingtype-question

Sweeny, R. T. (2005). Venting Library Buildings and Services for the Millennial Generation.Library Administration \& Management, 19(4), 165- 175

Wieler, A. (2005). Information-seeking behaviour in generation Y students: Motivation, critical thinking, and learning theory. Journal of Academic Librarianship, 31(1), 46-53.

Yoo-Lee, EunYoung, Lee, Heon Tae Lee and Velez, LaTesha (2013). "Planning library spaces and services for Millennials: an evidence-based approach", Library Management, 34(6/7), pp. $498-511$. 


\section{ANNEX}

Table 1: Millennials' expectations of services quality

\begin{tabular}{|c|c|c|c|c|c|c|}
\hline \multicolumn{2}{|c|}{ User expectations } & SD & D & $\mathbf{N}$ & $\mathbf{A}$ & S A \\
\hline \multicolumn{2}{|c|}{ Physical facilities } & & & & & \\
\hline E01 & $\begin{array}{l}\text { Spacious \& modern looking } \\
\text { building }\end{array}$ & & & $2 \%$ & $10 \%$ & $88 \%$ \\
\hline E02 & Easy physical access for the library & & & $1 \%$ & $5 \%$ & $94 \%$ \\
\hline E03 & Convenient library working hours & & & & & $100 \%$ \\
\hline E04 & Self-study areas in the library & & & & & $100 \%$ \\
\hline E05 & Group study areas in the library & & & & & $100 \%$ \\
\hline E06 & $\begin{array}{l}\text { Comfortable furniture and physical } \\
\text { facilities }\end{array}$ & & & & & $100 \%$ \\
\hline E07 & $\begin{array}{l}\text { Comfortable and inviting } \\
\text { environment ( } \mathrm{A} / \mathrm{C} \text { and lighting) }\end{array}$ & & & & $2 \%$ & $98 \%$ \\
\hline E08 & Coffee shop in the library building & & $10 \%$ & $35 \%$ & $21 \%$ & $24 \%$ \\
\hline \multicolumn{2}{|c|}{ Resources } & & & & & \\
\hline E09 & $\begin{array}{l}\text { Comprehensive Print Resources } \\
\text { (Books, journals etc.) }\end{array}$ & & & & & $100 \%$ \\
\hline E10 & $\begin{array}{l}\text { Leisure reading collection (novels/ } \\
\text { magazines) }\end{array}$ & & & $4 \%$ & $16 \%$ & $80 \%$ \\
\hline E11 & Good Collection of CDs/VCs & & & $4 \%$ & $14 \%$ & $82 \%$ \\
\hline E12 & $\begin{array}{l}\text { Subscription to e-journals/full-text } \\
\text { databases }\end{array}$ & & & $2 \%$ & $4 \%$ & $94 \%$ \\
\hline E13 & $\begin{array}{l}\text { Subscription to } \\
\text { statistical/bibliographical Databases }\end{array}$ & & & $8 \%$ & $16 \%$ & $78 \%$ \\
\hline E14 & $\begin{array}{l}\text { Proper arrangement of Print } \\
\text { Resources in the library }\end{array}$ & & & & $10 \%$ & $90 \%$ \\
\hline E15 & $\begin{array}{l}\text { State-of-Art computers in the } \\
\text { library }\end{array}$ & & & & $4 \%$ & $96 \%$ \\
\hline E16 & Printers and scanners in the library & & & & $8 \%$ & $92 \%$ \\
\hline E17 & $\begin{array}{l}\text { Electronic security/burglar system } \\
\text { in the library }\end{array}$ & & $29 \%$ & $30 \%$ & $22 \%$ & $19 \%$ \\
\hline E18 & $\begin{array}{l}\text { Well maintained computer \& other } \\
\text { equipment in library }\end{array}$ & & & & $11 \%$ & $89 \%$ \\
\hline E19 & $\begin{array}{l}\text { Self-checkout machines and drop } \\
\text { boxes }\end{array}$ & & & $2 \%$ & $12 \%$ & $86 \%$ \\
\hline \multicolumn{2}{|c|}{ Services } & & & & & \\
\hline E20 & $\begin{array}{l}\text { Internet connectivity and Wi-Fi } \\
\text { facilities }\end{array}$ & & & & & $100 \%$ \\
\hline E21 & $\begin{array}{l}\text { Automated Library operations and } \\
\text { services }\end{array}$ & & & $3 \%$ & $10 \%$ & $87 \%$ \\
\hline E22 & $\begin{array}{l}\text { Easy-to-use library on-line } \\
\text { catalogue (OPAC) }\end{array}$ & & & & $6 \%$ & $94 \%$ \\
\hline
\end{tabular}




\begin{tabular}{|c|c|c|c|c|}
\hline E23 & $\begin{array}{l}\text { Remote (Campus-wide) access to } \\
\text { Library Resources }\end{array}$ & & $2 \%$ & $98 \%$ \\
\hline E24 & $\begin{array}{l}\text { Library resources accessible } \\
\text { through Website }\end{array}$ & & $2 \%$ & $98 \%$ \\
\hline $\mathrm{E} 25$ & $\begin{array}{l}\text { Provision for on-line } \\
\text { reservations/renewals }\end{array}$ & $2 \%$ & $6 \%$ & $92 \%$ \\
\hline E26 & $\begin{array}{l}\text { Speed of response for Queries via } \\
\text { LAN/Internet }\end{array}$ & $6 \%$ & $10 \%$ & $84 \%$ \\
\hline E27 & $\begin{array}{l}\text { Networking with other libraries for } \\
\text { interlibrary lending }\end{array}$ & $32 \%$ & $36 \%$ & $32 \%$ \\
\hline E28 & Error free records in the library & & & $100 \%$ \\
\hline \multicolumn{5}{|l|}{ Staff } \\
\hline E29 & $\begin{array}{l}\text { Ability to promise services to users } \\
\text { by a certain time }\end{array}$ & & & $100 \%$ \\
\hline E30 & $\begin{array}{l}\text { Staff's sincere interest/willingness } \\
\text { to help users }\end{array}$ & & & $100 \%$ \\
\hline E31 & $\begin{array}{l}\text { Provision of "Right Document the } \\
\text { Very First Time" }\end{array}$ & $6 \%$ & $6 \%$ & $88 \%$ \\
\hline E32 & $\begin{array}{l}\text { Staff who instill trust/confidence in } \\
\text { users }\end{array}$ & $4 \%$ & $10 \%$ & $86 \%$ \\
\hline E33 & $\begin{array}{l}\text { Staff who understand the specific } \\
\text { needs of users. }\end{array}$ & & & $100 \%$ \\
\hline E34 & $\begin{array}{l}\text { Staff's Knowledge/competence to } \\
\text { answer user queries }\end{array}$ & & $8 \%$ & $92 \%$ \\
\hline
\end{tabular}

